\title{
REPEATABILITY OF PHYSICAL AND CHEMICAL CHARACTERISTICS IN PEQUI FRUITS ${ }^{1}$
}

\author{
BLENDA CALAZANS SOARES 2 , PAULO HENRIQUE RODRIGUES DOS SANTOS ${ }^{3}$, \\ FERNANDO HIGINO LIMA E SILVA ${ }^{4}$, ELIZABETHE ADRIANA ESTEVES ${ }^{5}$, \\ MIRANDA TITON ${ }^{6}$, JOSÉ SEBASTIÃO CUNHA FERNANDES ${ }^{7}$
}

ABSTRACT - The aim of this study was to estimate the effects of populations and mother trees over some characteristics on pequi (Caryocar brasiliense Camb.) fruits as well as their repeatability coefficient. Data came from two populations with 15 mother trees each, covering three years. The following physical and chemical characteristics were evaluated: total fruit weight; external mesocarp weight; number of putamens per fruit; total weight of putamens; total and average pulp weight; and proportion of the weight of lipids and proteins in relation to pulp weight. Analysis of variance was performed using a nested design model. The effects of mother trees within populations were highly significant for all variables under study, while the effects of populations were not for any characteristic, showing that for populations and mother trees, efforts must be focused on the number of mother trees per population rather than on populations. The estimated repeatability coefficients showed high genetic control for total fruit weight; external mesocarp weight; average weight of putamens; average pulp weight; and proportion of the weight of lipids in relation to pulp weight. Therefore, the expression of these characteristics on descendants, by cloning selected mother trees, is likely to be effective.

Index terms: Caryocar brasiliense, repeatability coefficient, mother trees.

\section{REPETIBILIDADE DE CARACTERÍSTICAS FÍSICAS E QUÍMICAS EM FRUTOS DE PEQUI}

RESUMO - O objetivo deste trabalho foi estimar os efeitos de populações, matrizes e do coeficiente de repetibilidade em frutos de pequizeiro (Caryocar brasiliense Camb.). Foram coletados dados de duas populações, por três anos consecutivos, das seguintes características: massa massa total do fruto; massa do mesocarpo externo; número de putâmens por fruto; massa total e média de putâmens; massa total e média da polpa; e a proporção da massa de lipídeos e proteínas em relação à massa total da polpa. A análise de variância foi feita usando-se um modelo de classificação hierárquica. Os efeitos de matrizes dentro de populações foram altamente significativos para todas as características estudadas, ao passo que os efeitos destas populações não o foram para nenhuma característica, evidenciando que no dimensionamento de testes de populações e progênies, deve-se optar pelo maior número de matrizes por população em detrimento do número de populações. As estimativas de repetibilidade encontradas permitem inferir um alto controle genético para as características massa total do fruto; massa do mesocarpo externo; massa média de putâmens; massa média da polpa; e teor de lipídeos e, portanto, uma maior probabilidade de expressão destas características nos descendentes clonais de matrizes selecionadas.

Termos para indexação: Caryocar brasiliense, coeficiente de repetibilidade, matrizes.

${ }^{1}$ (Paper 209-15). Received September 03, 2015. Accepted February 25, 2016.

${ }^{2}$ Agronomist, MSc. in Plant Production, UFVJM, Department of Agronomy, Diamantina-MG. Email: blendacalazans@hotmail.com ${ }^{3}$ Forest Engineer, PhD. student in Plant Production, UFVJM, Department of Agronomy, Diamantina-MG. Email: santosphr@yahoo.com.br

${ }^{4}$ Agronomist, PhD. Professor at IFG, Department of Agronomy, Rio Verde Campus - GO. Email: fernandohiginolima@gmail.com

${ }^{5}$ Nutritionist, PhD. Professor at UFVJM, Department of Nutrition, Diamantina-MG. Email: eaesteves@yahoo.com.br

${ }^{6}$ Forest Engineer, PhD. Professor at UFVJM, Department de Forest Engineering, Diamantina-MG. Email: titonmiranda@yahoo.com.br

${ }^{7}$ Agronomist, PhD. Professor at UFVJM, Department of Agronomy, Diamantina-MG. Email: jscf1912@gmail.com 


\section{INTRODUCTION}

Pequi (Caryocar spp. - Caryocaraceae) is a plant native to the Savanna and Amazon biomes, whose fruit is rich in oil and appreciated by the population living in these ecosystems (SILVA et al., 2001a). In addition, its pulp is a source of protein, vitamins and minerals, which makes its consumption in the elaboration of typical dishes, oil, liquor, and cosmetics more expressive (RIBEIRO, 2000; ANGELO et al., 2012). It stands out as a tree of multiple utilities, provides the maintenance of the extractive activity, is a temporary opportunity to offer food and income supplementation to populations living in these biomes, and it is mainly cultivated in northern Minas Gerais, northern and northeastern Goiás and southern and southeastern Tocantins (NAVES et al., 2010).

The effect of populations and mother trees on variations of characteristics such as fruit size and pulp thickness is popularly known by people living with the species. Researchers aimed at the genetic breeding of Pequi, attentive to the observations of these communities, perceive their preference for certain mother trees, whose fruits show some qualities, especially pulp thickness and flavor. This common sense leads to the perception that these effects are extensive to the weight of fruits, putamens, number of putamens per fruit, pulp weight, among others. Silva et al., (2012) reports the importance of studies of these effects on these characteristics for the validation of the selection of mother trees aiming at the production of seedlings and, ultimately, in the breeding and / or domestication of the species.

Another aspect that cannot be disregarded in perennial species is that the features under selection can be expressed several times during the life span of the individual. Thus, successive evaluations of such features are commonly performed for the improvement of the selection efficiency, from the estimation of an individual's ability to repeat the expression of a given feature over time. This capacity is called repeatability coefficient and the higher the coefficient, the smaller the number of evaluations needed to predict the individual's actual value (OLIVEIRA AND MOURA, 2010).

Therefore, repeatability estimates are very important for researchers working with such species. In addition, this coefficient represents the upper limit of heritability in the broad sense for a given feature (FALCONER, 1987; CRUZ \& REGAZZI, 1994; CRUZ \& REGAZZI, 2001). The implication of this latter assertion is the inevitable inference that if a given feature has high repeatability, it should also have high heritability. Therefore, although no information is available in this sense in literature, it is expected that there is a high correlation between repeatability and heritability in the broad sense. It should be emphasized that repeatability can be estimated from natural populations or even from nonclonal commercial crops, that is, produced from seeds harvested in several mother trees of the latter. This is the reason why repeatability has been estimated in fruit species, without the structure of experimental designs, such as coconut (SIQUEIRA, 1982), cupuaçu (FONSECA et al., 1990), cashew (CAVALCANTI at al.,1999), and acerola (GONZAGA NETO et al., 1999; PAIVA et al., 2001; LOPES et al., 2001). In clonal tests with repetition and several evaluations, it is possible to estimate both repeatability and heritability in the broad sense, allowing the comparison between the estimates of these two parameters (RESENDE, 2002), but such experiments are not commonly reported in literature.

The aim of this study was to estimate the effects of populations and mother trees as well as the repeatability coefficient for physical and chemical characteristics of pequi fruits (Caryocar brasiliense Camb.) of two geographically isolated populations.

\section{MATERIAL AND METHODS}

Analyses were carried out on fruits collected at Fazenda Experimental do Moura - UFVJM, municipality of Curvelo, and at the State Park of Rio Preto - IEF, municipality of São Gonçalo do Rio Preto, both in the State of Minas Gerais. The collection site in the municipality of Curvelo has coordinates $18^{\circ} 49^{\prime} 25.07^{\prime \prime S}$ and $44^{\circ} 24^{\prime} 12.82^{\prime}$ " W and $700 \mathrm{~m}$ a.s.l. (Google Earth, 2015) and average annual temperature of $28^{\circ} \mathrm{C}$. The collection site in the municipality of São Gonçalo do Rio Preto has coordinates $18^{\circ} 6^{\prime}$ '58.37 'S and $43^{\circ} 20^{\prime}$ ' $40.61^{\prime \prime} \mathrm{W}$ and $800 \mathrm{~m}$ a.s.l. (Google Earth, 2015) and average annual temperature of $19^{\circ} \mathrm{C}$. Both populations are natural and can be considered reproductively isolated, since the distance in a straight line between localities, considering these coordinates, is $137 \mathrm{~km}$.

Fruits were collected in the months of January 2010, 2011 and 2012, in a stage of complete maturation, that is, when fruits were lying on the ground, and then packed in a freezer until moment of analysis.

Fruits were harvested from 30 previously identified mother trees, 15 from each site in each year for the physical evaluations and, due to technical and cost limitations, fruits of ten of these mother trees 
were considered for the chemical evaluations, five of each municipality.

The physical characteristics analyzed were: total fruit weight (MTF); weight of the external mesocarp (MME); number of putamens per fruit (NP); total weight of putamens (MTP); mean weight of putamens (MMP); total pulp weight (MTPL) and average pulp weight (MMPL) - evaluated in grams. For statistical analyses, each evaluation unit (plot) was composed of one fruit and each mother tree was represented by ten fruits taken at random, totaling 300 (10 evaluations per mother tree x 30 mother trees per year) evaluations per characteristic per year.

The chemical characteristics analyzed included quantification of total lipids and proteins by means of the evaluation of previously dehumidified and crushed fruit pulp. Fruits were peeled and hand pulped with the help of a stainless steel knife and the pulp was kept frozen until moment of analyses.

Due to technical difficulties (limitation of equipment, time, reagents and costs), it was not possible to evaluate the same number of fruits per mother tree and mother trees per population that were evaluated for the physical characteristics. Each mother tree was represented by three random sub-samples of three fruits each, and observation for each sub-sample was the average of three evaluations (triplicate), totaling 90 evaluations (three evaluations per sample $\mathrm{x}$ three samples per mother tree $\mathrm{x} 10$ mother trees per year) per characteristic per year. The option for three samples of three fruits each instead of simply three fruits per mother tree is justified since the first option represents the mother tree better. In addition, the variation among three samples composed of three fruits each is smaller than the variation among three samples composed of one fruit each, increasing the power of the $\mathrm{F}$ test for the effects of mother trees within populations.

The dehumidification of samples was carried out using the method of drying in oven with forced air circulation at temperature of $65^{\circ} \mathrm{C}$ until obtaining constant weight (AOAC, 2005). Lipids, or ethereal extract, were determined by the gravimetric method through exhaustive leaching using ethyl ether in a Soxhlet extractor (AOAC, 2005). Total nitrogen, or crude protein, was obtained through the Kjeldahl semimicro method (AOAC, 2005), where fat-free samples were used and 6.25 factor in the calculation of conversion of nitrogen into protein.

The analyses, for each year, followed a hierarchical classification based on the model: $\mathrm{Y}_{\mathrm{ijk}}=$ $\mathrm{m}+\mathrm{P}_{\mathrm{i}}+\mathrm{M}_{\mathrm{j} / \mathrm{i}}+\mathrm{F}_{\mathrm{k} / \mathrm{ji}}$, where: $\mathrm{Y}_{\mathrm{ijk}}$ refers to the observation of fruit kt within mother tree $\mathrm{j}$ within population $\mathrm{i}$; $\mathrm{m}=$ general average; $\mathrm{P}_{\mathrm{i}}=$ effect of population $\mathrm{i} ; \mathrm{M}_{\mathrm{j} / \mathrm{i}}$
$=$ effect of mother tree $\mathrm{j}$ within population $\mathrm{i}$; and $\mathrm{F}_{\mathrm{k}}$ ${ }_{\mathrm{ji}}$ is the effect of fruit $\mathrm{k}$ within mother tree $\mathrm{j}$ within population i (DIAS \& BARROS, 2009).

In the analysis of the combined variance involving the three years, only the 20 mother trees common to the three years were considered, nine from Curvelo and 11 from São Gonçalo do Rio Preto for the physical characteristics, and eight mother trees, four from each population for the chemical characteristics. The model for this analysis was $\mathrm{Y}_{\mathrm{ijk}}=\mathrm{m}+(\mathrm{M}+\mathrm{P})_{\mathrm{i}}+\mathrm{A}_{\mathrm{j}}+(\mathrm{M}+\mathrm{P}) \mathrm{A}_{\mathrm{ij}}+\mathrm{F}_{\mathrm{k} / \mathrm{jj}}$ where $\mathrm{Y}_{\mathrm{ijk}}$ refers to the observation of fruit $k$ of year $j$ of mother tree $\mathrm{i}$, including the effect of population; $\mathrm{m}$ is the general average; $A_{j}$ refers to year $j ;(M+P) A_{i j}$ is the interaction between mother tree $\mathrm{i}$, including the effect of population, and year $\mathrm{j}$; and $\mathrm{F}_{\mathrm{k} / \mathrm{j}}$ is the effect of fruit $\mathrm{k}$ on environment $\mathrm{j}$ of mother tree $\mathrm{i}$, including the effect of population (DIAS \& BARROS, 2009).

The degrees of freedom and respective sums of squares for the effect $(\mathrm{M}+\mathrm{P}) \mathrm{A}_{\mathrm{ij}}$ were orthogonally decomposed into their components: Populations and Mother trees within populations and the latter in mother trees within Rio Preto and mother trees within Curvelo (Table 1 ).

The repeatability coefficient $(\mathrm{R})$ was estimated from the mean squares (Table 1), as follows:

$$
\begin{aligned}
& \mathrm{R}_{\mathrm{C}}=\frac{\mathrm{V}_{\mathrm{m} / \mathrm{C}}}{\mathrm{V}_{\mathrm{m} / \mathrm{C}}+\mathrm{V}_{\mathrm{et}}} ; \mathrm{R}_{\mathrm{RP}}=\frac{\mathrm{V}_{\mathrm{m} / \mathrm{RP}}}{\mathrm{V}_{\mathrm{m} / \mathrm{RP}}+\mathrm{V}_{\mathrm{et}}} ; \\
& \mathrm{R}=\frac{\mathrm{V}_{\mathrm{m} / \mathrm{P}}}{\mathrm{V}_{\mathrm{m} / \mathrm{P}}+\mathrm{V}_{\mathrm{et}}} ; \mathrm{R}^{2}=\frac{\mathrm{V}_{\mathrm{m} / \ldots}}{\mathrm{V}_{\mathrm{m} / . .}+\mathrm{V}_{\mathrm{et}} / 3},
\end{aligned}
$$

were $R_{C}, R_{R P}$ and $R$ refer to the repeatability coefficient for Curvelo, Rio Preto and combination, respectively; and $\mathrm{V}_{\mathrm{m} / \mathrm{C}}, \mathrm{V}_{\mathrm{m} / \mathrm{RP}}$ and $\mathrm{V}_{\mathrm{m} / \mathrm{P}}$ refer to the mother tree variance of Curvelo, Rio Preto and populations. For the estimation of the determination coefficient $\left(R^{2}\right)$ that is equivalent to the repeatability of the mean, $V_{e t}$ (Variance of the temporary error) was divided by the number of years ( 3 years) in each of the previous expressions (CRUZ \& REGAZZI, 2001).

\section{RESULTS AND DISCUSSION}

\section{Physical characteristics}

The effect of population was not significant for any characteristic. For all other characteristics, all effects were significant ( $p<0.05$ ), except for the effect of years $x$ population + mother trees interaction on the NP characteristic (Table 02). In tree species, 
it is not uncommon to find greater genetic variation within the population than among populations (YUN et al 1998, AAGAARD et al., 1998). For the species under study, the low divergence among populations should be due to the high gene flow among them due to the pollination system of the species (VILELA, 1998; MELO JR et al., 2004), which is mainly performed by bats (GRIBEL \& HAY, 1993), whose flight reaches great distances, and also to the dispersion of seeds that is carried out by great birds and some mammals. What we currently consider as isolated populations would be the result of the fragmentation of a single large population not long enough to cause divergences between them.

The average values for the physical characteristics of mother trees evaluated in years 2010, 2011 and 2012 in both populations are shown in Table 03. For total fruit weight (g), the results of this work were similar to those of Silva et al., (2001b) for pequi fruits of the Federal District region, with results between $100 \mathrm{~g}$ and $300 \mathrm{~g}$, and higher than those reported by Rodrigues et al., (2009), which recorded a final mean value of $109 \mathrm{~g}$, evaluating the development of pequi fruits in southern Minas Gerais.

As for the weight (g) of the external mesocarp (MME), the mean values among mother trees (Table 03) are similar to values of Alves et al., (2014), who found fruits weighing between 53.8 and $343.9 \mathrm{~g}$, with average value of $144.9 \mathrm{~g}$, in the state of Minas Gerais. Considered as a residue, pequi skin (external mesocarp) is usually discarded, but it can serve as feed for grazing ruminants and used as bran in mixtures with silage and, or, replacement of elephant grass (GERASEEV et al., 2011). Its thicker and yellowish-white layer has high fiber content, which when used for the confection of flour and added in different food formulations, adds nutritional and economic value to this fruit (SOARES JÚNIOR et al., 2009).

In relation to the number of putamen (NP), the mean values per mother tree (Table 03) are similar to data reported by Alves et al., (2014), who verified mean values of 1.3 for pequis from Minas Gerais and Tocantins and 1.5 for pequis from Goiás. Vera et al. (2007) observed higher incidence of fruits with only one developed putamen. In addition to the pulp, a greater amount of putamens per fruit makes it more attractive due to the greater number of almonds, commonly used for fresh fruit consumption and in the manufacture of flour, oil, among others.

As for the average weight ( $\mathrm{g}$ ) of putamens (MMP), Vera et al. (2007) observed mean value of $11.46 \mathrm{~g}$ for the region of Mambaí and $13.80 \mathrm{~g}$ for the region of Araguapaz, state of Goiás, values close to the minimum average, but well below the upper average found (Table 03). In relation to the total weight of putamens (MTP), Corrêa et al. (2008) reported higher values ranging from $32.49 \mathrm{~g}$ to $138.37 \mathrm{~g}$ and with mean value of $81.05 \mathrm{~g}$.

The results for total pulp weight (MTPL), a highly valued characteristic (Table 3 ), were close to those reported by Da Luz et al., (2011), who found mean value of $14.3 \mathrm{~g}$, minimum value of $3.5 \mathrm{~g}$ and maximum value of $31.4 \mathrm{~g}$, for pequis from the state of Minas Gerais, while for the average pulp weight (MMPL) (Table 03), the values were within those reported by Vera et al. (2005), who observed mean pulp weight of $7.26 \mathrm{~g}$ in the state of Goiás (Table 2). In selection programs, fruits with a higher total pulp weight are more desired than those with higher average pulp weight per putamen (Silva et al., 2012).

Another remarkable aspect is the magnitude of variation observed among mother trees for the characteristics under study. The lowest amplitude (difference between the highest and the lowest mean) was $44 \%$ for NP characteristic and the highest was $169 \%$ for the MME characteristic for the population of Curvelo (Table 3). For the population of Rio Preto, the lowest amplitude observed was also for NP (53\%) and the largest (281\%) was for MTPL (Table 03). These magnitudes of variation practically do not change when considering all mother trees as a single population (Table 3), which was expected since, as previously discussed, the effects of populations were not significant for any characteristic, i.e., most of the variation observed is among mother trees within populations.

The estimates of the repeatability $(\mathrm{R})$ and determination coefficients $\left(\mathrm{R}^{2}\right)$ for the physical characteristics evaluated are shown in Table 04. $\mathrm{R}$ estimates above 0.6 for MTF in Curvelo; MME in Curvelo and combination; MMP in Curvelo, Rio Preto and combination and MMPL in Rio Preto and combination were observed. Except for NP in Curvelo where $\mathrm{R}<0.3$, $\mathrm{R}$ estimates for the remaining characteristics were between 0.3 and 0.6 .

The classification of these estimates within such limits is in agreement with considerations made by Resende (2002), which considers R estimates higher than 0.60 as high; between 0.30 and 0.60 as intermediate and below 0.30 as low. On the other hand, considering that repeatability expresses the maximum heritability value in the broad sense and that the latter reflects the genetic control of the feature (CRUZ; REGAZZI, 2001), one can make inferences regarding the genetic control of these characteristics from estimates of their repeatability. 
Repeatability has been used in several species in order to increase the efficiency of selection methods. Resende (2002), Costa et al. (1997), in a study with Cupuaçu fruits, found repeatability values of 0.77 for fruit weight and Fonseca et al., (1990) also with Cupuaçu fruits, reported repeatability of 0.61 for pulp weight; 0.58 for skin weight; and 0.56 for total fruit weight.

With respect to $\mathrm{R}^{2}$, it is observed that its relative increase in relation to repeatability is greater for characteristics where repeatability is smaller (Table 04). This is natural since in the expression for $\mathrm{R}^{2}$, the variance of the temporary error is divided by the number of measurements, asymptotically approaching the unit when the number of measurements is increased.

Through estimates of the number of assessments required for $\mathrm{R}^{2}$ of $80 \%$, which is considered adequate according to Resende (2002), it was observed that the number of evaluations performed in this work (three years) was sufficient for the three characteristics in Curvelo (MTP, MMP, MTPL and MMPL) and four in combination (MTF, MME, MMP and MMPL), which shows regularity in the prediction of individuals from one cycle to another (Table 04). On the other hand, for almost all the characteristics, except for NP in Curvelo, seven evaluations (ranging from 0.7 to 7.1 ) were sufficient to have $\mathrm{R}^{2}$ of $80 \%$.

The comparison among estimates given in Table 03 (particularly the variation magnitude) and Table $04\left(\mathrm{R}, \mathrm{R}^{2}\right.$, and $\mathrm{m}$ ) is worth highlighting. It is naturally expected that characteristics that present greater variation magnitude among mother trees should correspond to those with greater repeatability and determination and, consequently, require lower number of measurements to reach a predetermined determination, in this work, $80 \%$. This trend can be observed in these tables, where the estimate of $\mathrm{m}$ for NP was the highest in combination (Table 04) and the variation magnitude was the lowest in both populations and in combination (Table 03).

On the other hand, considering that repeatability is the upper limit of heritability in the broad sense, the first parameter can be used in an initial phase as a reference for the selection of mother trees in the field since it reflects the genetic control of the feature (CRUZ; REGAZZI, 2001). For clonal plantings, particularly for characteristics whose repeatability estimates are greater than $60 \%$, greater probability that the expression of these characteristics are repeated in the offspring is expected.

\section{Chemical Characteristics}

Except for populations, all effects were significant $(\mathrm{P}<0.01)$ for both lipids and proteins (Table 05). Therefore, the same observations made for the physical characteristics are valid for the chemical characteristics where, in arboreal species, the greatest genetic variation is found within populations (YUN et al., 1998; AAGAARD et al., 1998).

The average values of the chemical characteristics of mother trees evaluated in the years 2010, 2011 and 2012 in both populations are shown in Table 06. Estimates for lipids expressed in fresh matter in the averages of the three years of evaluation were slightly above data reported by Oliveira et al. (2010), who found average value of around 23\%, and also to those of Vera et al. (2007), who obtained results from $14.8 \%$ to $22.5 \%$ in two regions. However, Vera et al., (2007) observed a significant effect $(\mathrm{p}<0.05)$ among populations of their study, Mambaí and Araguapaz, in the state of Goiás.

The protein values expressed in fresh matter, in the average of the three years of study (Table $06)$, are in agreement with data of Ramos \& Souza (2011), who observed for two populations $3.57 \%$ in pequi fruits (Caryocar coriaceum Wittm). Similar results in Caryocar brasiliense Camb. were also obtained by Lima et al., (2007). Vera et al., (2007) found very close values, mean of $3.89 \%$ and $3.18 \%$, observing, however, significant effect $(p<0.05)$ for the populations under study. It is noteworthy that the relative magnitude of variation observed for these characteristics when considering the set, where lipid content varied from $19.16 \%$ to $39.45 \%$ and that of proteins from $2.26 \%$ to $3.62 \%$, with relative magnitudes of $106 \%$ and $60 \%$, respectively (Table 06).

In relation to the estimates of the repeatability (R) and determination coefficients $\left(\mathrm{R}^{2}\right)$, it was observed that for lipids, the repeatability estimates are around $60 \%$ (Table 07 ), and all three evaluations were sufficient to reach determination of $80 \%$ (Table 07). However, the protein characteristic showed repeatability below $30 \%$ for both sites and for the combination (Table 07), requiring more than ten evaluations to reach $80 \%$ determination (Table 07 ).

The estimate of the repeatability coefficient of the lipid characteristic demonstrates regularity in the prediction of individuals from one cycle to another, indicating that this characteristic can be used in the phenotypic selection of pequi tree genotypes. However, the protein characteristic did not show the same behavior, where greater number of evaluations 
is necessary to estimate the actual value, considering the same precision level.

Recalling that repeatability reflects the genetic control of a characteristic (CRUZ; REGAZZI, 2001) and that $\mathrm{R}$ estimates above 0.60 are considered high (Resende, 2002), the same inferences raised for the physical characteristics can be made for the chemical characteristics (Tables 06 and 07), that is, greater probability that the expression of the lipid characteristic will be repeated in the offspring by vegetative propagation of selected mother trees is expected.

TABLE 1- Combined variance analysis for physical and chemical characteristics of pequi fruits collected in mother trees of two populations (São Gonçalo do Rio Preto and Curvelo, MG) for three consecutive years, 2010, 2011 and 2012

\begin{tabular}{|l|c|c|c|c|}
\hline \multicolumn{1}{|c|}{ SV } & $\begin{array}{c}\text { DF } \\
\text { (Physical C.) }\end{array}$ & $\begin{array}{c}\text { DF } \\
\text { (Chemical } \\
\text { C.) }\end{array}$ & MS & $\begin{array}{c}\text { Expectes } \\
\text { value } \\
\text { of MS }\end{array}$ \\
\hline Populations + Mother trees & 19 & 7 & & \\
\hline Populations & 1 & 1 & & \\
\hline Mother trees / Populations & 18 & 6 & $\mathrm{MS}_{\mathrm{m} / \mathrm{P}}$ & $\mathrm{V}_{\mathrm{et}}+3 \mathrm{~V}_{\mathrm{m} / \mathrm{P}}$ \\
\hline Mother trees /Curvelo & 8 & 3 & $\mathrm{MS}_{\mathrm{m} / \mathrm{C}}$ & $\mathrm{V}_{\mathrm{et}}+3 \mathrm{~V}_{\mathrm{m} / \mathrm{C}}$ \\
\hline Mother trees /R. Preto & 10 & 3 & $\mathrm{MS}_{\mathrm{m} / \mathrm{RP}}$ & $\mathrm{V}_{\mathrm{et}}+3 \mathrm{~V}_{\mathrm{m} / \mathrm{RP}}$ \\
\hline Years & 2 & 2 & & \\
\hline Years x (Populations + Mother trees) & 38 & 14 & $\mathrm{MS}_{\mathrm{et}}$ & $\mathrm{V}_{\mathrm{et}}$ \\
\hline Among fruits/ Mother trees & 540 & 48 & & \\
\hline Total & $\mathbf{5 9 9}$ & $\mathbf{7 1}$ & & \\
\hline
\end{tabular}

$\mathrm{MS}_{\mathrm{m} / \mathrm{P}}$ : Mean square of mother trees / populations; $\mathrm{MS}_{\mathrm{m} / \mathrm{C}}$ : Mean square of matrices / Curvelo; $\mathrm{MS}_{\mathrm{m} / \mathrm{RP}}$ : Mean square of mother trees / Rio Preto; $\mathrm{MS}_{\mathrm{et}}$ : Mean square of the temporary error; $\mathrm{V}_{\mathrm{et}}$ : Variance of the temporary error; $\mathrm{V}_{\mathrm{m} / \mathrm{P}}:$ mother tree variance / population; $\mathrm{V}_{\mathrm{m} / \mathrm{C}}:$ mother tree variance / Curvelo; $\mathrm{V}_{\mathrm{m} / \mathrm{RP}}$ : mother tree variance / Rio Preto.

TABLE 2- Combined variance analysis for physical characteristics ${ }^{1}$ and their respective probabilities of significance P (F) for pequi fruits (Caryocar brasiliense Camb.) evaluated in the years 2010, 2011 and 2012, harvested in mother trees from the municipalities of Curvelo (Fazenda Experimental do Moura -UFVJM) and São Gonçalo do Rio Preto (State Park of Rio Preto IEF), Minas Gerais

\begin{tabular}{|c|c|c|c|c|c|c|c|c|}
\hline \multirow{3}{*}{ SV } & \multirow{3}{*}{ DF } & \multicolumn{7}{|c|}{$\mathbf{P}(\mathbf{F}) \%$} \\
\hline & & \multicolumn{7}{|c|}{ Characteristics } \\
\hline & & MTF & MME & NP & MTP & ММР & MTPL & MMPL \\
\hline Populations + Mother trees & 19 & 0.00 & 0.00 & 0.00 & 0.00 & 0.00 & 0.00 & 0.00 \\
\hline Populations & 1 & 8.78 & 8.65 & 38.92 & 54.73 & 38.37 & 32.11 & 21.64 \\
\hline Mother trees / Populations & 18 & 0.00 & 0.00 & 0.00 & 0.00 & 0.00 & 0.00 & 0.00 \\
\hline Mother trees /Curvelo & 8 & 0.00 & 0.00 & 1.55 & 0.00 & 0.00 & 0.00 & 0.00 \\
\hline Mother trees /R. Preto & 10 & 0.00 & 0.00 & 0.00 & 0.00 & 0.00 & 0.00 & 0.00 \\
\hline Years & 2 & 0.00 & 0.00 & 2.19 & 0.00 & 0.00 & 0.00 & 0.00 \\
\hline Years x (Populations + Mother trees) & 38 & 0.00 & 0.00 & 6.72 & 0.00 & 0.00 & 0.00 & 0.00 \\
\hline Among fruits/ Mother trees & 540 & & & & & & & \\
\hline Total & 599 & & & & & & & \\
\hline
\end{tabular}

${ }^{1}$ MTF: total fruit weight (g); weight of the external mesocarp (g); NP: number of putamens (g); MTP: total weight of putamens (g); MMP: mean weight of putamens (g); MTPL: total pulp weight (g); MMPL: mean pulp weight (g). Variation coefficients were estimated considering QM and the general average for both populations in the three years of evaluation. 
TABLE 3 - Estimates of averages for physical characteristics ${ }^{1}$ for pequi fruits (Caryocar brasiliense Camb.) evaluated in the years 2010, 2011 and 2012, harvested in mother trees from the municipalities of Curvelo (Fazenda Experimental do Moura -UFVJM) and São Gonçalo do Rio Preto (State Park of Rio Preto - IEF), Minas Gerais.

\begin{tabular}{|c|c|c|c|c|c|c|c|c|}
\hline Population & Mother tree & MTF & MME & NP & MTP & MMP & MTPL & MMPL \\
\hline Curvelo & 1 & 116.30 & 74.21 & 1.63 & 42.09 & 26.37 & 20.79 & 13.04 \\
\hline Curvelo & 4 & 133.48 & 96.61 & 1.83 & 36.87 & 20.07 & 14.73 & 8.11 \\
\hline Curvelo & 6 & 174.98 & 148.38 & 1.27 & 26.60 & 21.58 & 10.49 & 8.51 \\
\hline Curvelo & 8 & 157.92 & 129.69 & 1.37 & 28.24 & 20.78 & 14.44 & 10.62 \\
\hline Curvelo & 11 & 145.78 & 115.18 & 1.47 & 30.60 & 21.28 & 14.71 & 10.18 \\
\hline Curvelo & 17 & 215.48 & 173.53 & 1.53 & 41.95 & 27.13 & 19.90 & 12.81 \\
\hline Curvelo & N02 & 154.01 & 115.81 & 1.50 & 38.20 & 25.97 & 17.26 & 11.62 \\
\hline Curvelo & N03 & 144.52 & 117.73 & 1.73 & 26.80 & 15.76 & 11.56 & 6.87 \\
\hline Curvelo & N05 & 243.15 & 199.68 & 1.80 & 43.47 & 25.33 & 17.84 & 10.41 \\
\hline \multirow{2}{*}{\multicolumn{2}{|c|}{$\begin{array}{l}\text { Mean Curvelo } \\
\text { Mag. of char. Curvelo }\end{array}$}} & 165.07 & 130.09 & 1.57 & 34.98 & 22.70 & 15.75 & 10.24 \\
\hline & & 126.85 & 125.47 & 0.56 & 16.87 & 11.37 & 10.30 & 6.17 \\
\hline Rio Preto & 151 & 181.03 & 125.33 & 1.90 & 55.71 & 30.08 & 26.02 & 14.18 \\
\hline Rio Preto & 167 & 156.22 & 126.68 & 2.00 & 29.54 & 15.59 & 11.56 & 6.17 \\
\hline Rio Preto & 168 & 155.47 & 128.19 & 2.03 & 27.29 & 13.63 & 12.65 & 6.34 \\
\hline Rio Preto & 172 & 127.97 & 95.67 & 1.97 & 32.30 & 17.02 & 13.60 & 7.24 \\
\hline Rio Preto & 174 & 155.67 & 124.50 & 1.73 & 31.17 & 18.91 & 11.80 & 7.11 \\
\hline Rio Preto & N151 & 146.66 & 102.80 & 1.37 & 43.86 & 32.69 & 18.26 & 13.67 \\
\hline Rio Preto & N154 & 147.69 & 118.96 & 1.33 & 28.73 & 22.76 & 12.81 & 10.29 \\
\hline Rio Preto & N156 & 100.69 & 83.68 & 1.37 & 17.01 & 12.85 & 6.83 & 5.08 \\
\hline Rio Preto & N158 & 109.24 & 81.56 & 1.67 & 27.68 & 16.53 & 12.04 & 7.29 \\
\hline Rio Preto & N159 & 128.77 & 95.71 & 1.53 & 33.06 & 22.30 & 11.84 & 8.06 \\
\hline Rio Preto & N160 & 117.36 & 85.39 & 1.43 & 31.97 & 23.35 & 14.04 & 10.35 \\
\hline \multirow{2}{*}{\multicolumn{2}{|c|}{$\begin{array}{l}\text { Média Rio Preto } \\
\text { Mag. of char. Rio Preto }\end{array}$}} & 138.80 & 106.22 & 1.67 & 32.57 & 20.52 & 13.77 & 8.71 \\
\hline & & 80.34 & 46.63 & 0.70 & 38.70 & 19.84 & 19.19 & 2.79 \\
\hline \multicolumn{2}{|c|}{ Mag. of char. total } & 142.46 & 125.47 & 0.76 & 38.7 & 19.84 & 19.19 & 9.1 \\
\hline \multicolumn{2}{|l|}{ DMS } & 40.28 & 29.43 & 0.62 & 12.29 & 3.40 & 5.43 & 1.72 \\
\hline
\end{tabular}

${ }^{1}$ MTF: total fruit weight (g); Weight of the external mesocarp (g); NP: number of putamens (g); MTP: total weight of putamens (g); MMP: mean weight of putamens (g); MTPL: total pulp weight (g); MMPL: mean pulp weight (g).

DMS (minimum significant difference) (Tukey $5 \%$ significance): refers to DMS for multiple comparisons among mother trees for the two populations.

Mag. of char. (magnitude of characteristics): refers to the difference between the maximum and minimum values for the characteristic. 
TABLE 4- Estimates of the repeatability $(\mathrm{R})$ and determination coefficients $\left(\mathrm{R}^{2}\right)$ and number of evaluations required $(\mathrm{m})$ for a $80 \%$ determination $\left(\mathrm{R}^{2}\right)$ estimated based on the repeatability for physical characteristics $^{1}$ evaluated in the years 2010, 2011 and 2012, in pequi fruits (Caryocar brasiliense Camb.) originating from mother trees from the municipalities of Curvelo (Fazenda Experimental do Moura -UFVJM) and São Gonçalo do Rio Preto (State Park of Rio Preto - IEF), Minas Gerais

\begin{tabular}{|l|c|c|c|c|c|c|c|c|c|c|}
\hline \multirow{2}{*}{ Characteristics } & \multicolumn{3}{|c|}{ Curvelo } & \multicolumn{3}{c|}{ Rio Preto } & \multicolumn{3}{c|}{ Combination } \\
\cline { 2 - 11 } & $\mathbf{R}(\%)$ & $\mathbf{R}^{\mathbf{2}}(\%)$ & $\mathbf{m}$ & $\mathbf{R}(\%)$ & $\mathbf{R}^{\mathbf{2}}(\%)$ & $\mathbf{m}$ & $\mathbf{R}(\%)$ & $\mathbf{R}^{\mathbf{2}}(\%)$ & $\mathbf{m}$ \\
\hline MTF & 71.0 & 88.0 & 1.6 & 39.5 & 66.2 & 6.1 & 59.2 & 81.3 & 2.8 \\
\hline MME & 79.9 & 92.3 & 1.0 & 41.0 & 67.6 & 5.8 & 68.3 & 86.6 & 1.9 \\
\hline NP & 19.5 & 42.1 & 16.5 & 45.0 & 71.1 & 4.9 & 36.0 & 62.8 & 7.1 \\
\hline MTP & 36.2 & 63.0 & 7.1 & 59.9 & 81.8 & 2.7 & 52.0 & 76.5 & 3.7 \\
\hline MMP & 62.4 & 83.3 & 2.4 & 84.6 & 94.3 & 0.7 & 79.3 & 92.0 & 1.1 \\
\hline MTPL & 36.5 & 63.3 & 7.0 & 58.5 & 80.9 & 2.8 & 51.0 & 75.7 & 3.9 \\
\hline MMPL & 55.5 & 78.9 & 3.2 & 74.7 & 89.9 & 1.4 & 68.7 & 86.8 & 1.8 \\
\hline
\end{tabular}

${ }^{1}$ MTF: total fruit weight (g); Weight of the external mesocarp (g); NP: number of putamens (g); MTP: total weight of putamens (g); MMP: mean weight of putamens (g); MTPL: total pulp weight (g); MMPL: mean pulp weight (g).

TABLE 5-Analysis of the variance of chemical characteristics and their respective probabilities of significance P (F) for pequi fruits (Caryocar brasiliense Camb.) evaluated in the years 2010, 2011 and 2012, harvested in mother trees from the municipalities of Curvelo (Fazenda Experimental do Moura -UFVJM) and São Gonçalo do Rio Preto (State Park of Rio Preto - IEF), Minas Gerais

\begin{tabular}{|l|cc|c|}
\hline \multirow{2}{*}{ SV } & \multicolumn{3}{c|}{ P(F) \% } \\
\cline { 3 - 4 } & & DF & \multicolumn{2}{c|}{ Characteristics } \\
\cline { 3 - 4 } & & Lipids & Proteins \\
\hline Populations + Mother trees & 7 & 0.00 & 0.00 \\
Populations & 1 & 30.91 & 7.03 \\
Mother trees / Populations & 6 & 0.00 & 0.00 \\
Mother trees /Curvelo & 3 & 0.00 & 0.01 \\
Mother trees /R. Preto & 3 & 0.00 & 0.05 \\
Years & 2 & 0.00 & 0.00 \\
Years x (Populations + Mother trees) & 14 & 0.01 & 0.03 \\
Among fruits/ Mother trees & 48 & & \\
\hline Total & $\mathbf{7 1}$ & & \\
\hline
\end{tabular}

Variation coefficients were estimated considering MS years of evaluation. 
TABLE 6 - Estimates of averages for chemical characteristics ${ }^{1}$ for pequi fruits (Caryocar brasiliense Camb.) evaluated in the years 2010, 2011 and 2012, harvested in mother trees from the municipalities of Curvelo (Fazenda Experimental do Moura -UFVJM) and São Gonçalo do Rio Preto (State Park of Rio Preto - IEF), Minas Gerais

\begin{tabular}{|l|c|c|c|}
\hline \multicolumn{1}{|c|}{ Population } & Mother tree & Lipids (\%) & Proteins (\%) \\
\hline Curvelo & 6 & 27.14 & 3.07 \\
\hline Curvelo & 11 & 26.78 & 3.62 \\
\hline Curvelo & 17 & 39.45 & 2.73 \\
Curvelo & $\mathrm{N} 05$ & 26.74 & 3.36 \\
\hline Mean Curvelo & $\mathbf{3 0 . 0 3}$ & $\mathbf{3 . 1 9}$ \\
Mag. of char. Curvelo & $\mathbf{1 2 . 7 1}$ & $\mathbf{0 . 8 9}$ \\
\hline Rio Preto & 151 & 22.04 & 2.57 \\
\hline Rio Preto & 172 & 19.16 & 2.26 \\
\hline Rio Preto & 174 & 29.62 & 2.70 \\
Rio Preto & $\mathrm{N} 151$ & 30.56 & 3.04 \\
\hline Mean Rio Preto & $\mathbf{2 5 . 3 5}$ & $\mathbf{2 . 6 4}$ \\
Mag. of char Rio Preto & $\mathbf{1 1 . 4}$ & $\mathbf{0 . 7 8}$ \\
\hline Mag. of char total & $\mathbf{2 0 . 2 9}$ & $\mathbf{1 . 3 6}$ \\
\hline DMS & $\mathbf{3 . 6 5}$ & $\mathbf{0 . 4 3}$ \\
\hline
\end{tabular}

${ }^{1}$ Data expressed as fresh matter.

DMS (minimum significant difference) (Tukey 5\% significance): refers to DMS for multiple comparisons among mother trees within each population.

Mag. of char. (magnitude of characteristic): refers to the difference between the maximum and minimum value for the characteristic.

TABLE 7 - Estimates of the repeatability $(\mathrm{R})$, determination coefficients $\left(\mathrm{R}^{2}\right)$ and number of evaluations required $(\mathrm{m})$ for a $80 \%$ determination $\left(\mathrm{R}^{2}\right)$ estimated based on the repeatability for physical characteristics $^{1}$ evaluated in the years 2010, 2011 and 2012, in pequi fruits (Caryocar brasiliense Camb.) originating from mother trees from the municipalities of Curvelo (Fazenda Experimental do Moura -UFVJM) and São Gonçalo do Rio Preto (State Park of Rio Preto - IEF), Minas Gerais.

\begin{tabular}{|l|c|c|c|c|c|c|c|c|c|}
\hline \multirow{2}{*}{ Characteristics } & \multicolumn{3}{|c|}{ Curvelo } & \multicolumn{3}{c|}{ Rio Preto } & \multicolumn{3}{c|}{ Combination } \\
\cline { 2 - 10 } & $\mathbf{R}(\%)$ & $\left.\mathbf{R}^{\mathbf{2}} \mathbf{\%}\right)$ & $\mathbf{m}$ & $\mathbf{R}(\%)$ & $\mathbf{R}^{2}(\mathbf{\%})$ & $\mathbf{m}$ & $\mathbf{R}(\mathbf{\%})$ & $\mathbf{R}^{\mathbf{2}} \mathbf{( \% )}$ & $\mathbf{m}$ \\
\hline Lipids & 63.1 & 83.7 & 2.3 & 56.5 & 79.6 & 3.1 & 60.1 & 81.9 & 2.7 \\
Proteins & 27.6 & 53.3 & 10.5 & 14.8 & 34.2 & 23.1 & 21.7 & 45.4 & 14.4 \\
\hline
\end{tabular}




\section{CONCLUSIONS}

The effects of mother trees within populations were highly significant for all characteristics studied, whereas the effects of these populations were not for any characteristic, evidencing that in the sizing of tests of populations and progenies, larger number of mother trees per population to the detriment of the number of populations should be selected.

The repeatability estimates found allow inferring a high genetic control for characteristics total fruit weight; weight of the external mesocarp; average weight of putamens; average pulp weight; and lipid content and, therefore, greater probability of Aexpression of these characteristics in the clonal descendants of selected mother trees.

\section{ACKNOWLEDGMENTS}

To CAPES, FAPEMIG and UFVJM for the technical and financial support of this study.

\section{REFERENCES}

AAGAARD, J. E.; KRUTOVSKII, K. V. \& STRAUSS, S. H., 1998. RAPDs and allozymes exhibit similar levels of diversity and differentiations among populations and races of Douglas-fir. Heredity, Essex, v.81, n.1, p.69-78, 1998.

ALVES, A.M.; FERNANDES, D.C.; SOUSA, A.G.O.; NAVES. R.V.; NAVES, M.M.V. Características físicas e nutricionais de pequis oriundos dos estados de Tocantins, Goiás e Minas Gerais. Brazilian Journal of Food Technology, Campinas, v.17, n.3, p.198-203. 2014.

ANGELO, H.; POMPAMAYER, R.S.; VIANA, M.C.; ALMEIDA, A.N.; MOREIRA, J.M.M.A.P.; SOUZA, A.N. Valoração econômica da depredação do Pequi (Caryocar brasiliense Camb.) no Cerrado brasileiro. Scientia Forestalis, Piracicaba, v.40, n.93, p.35-45, 2012.

AOAC - Association of Official Analytical Chemistry. Official methods of analysis of the Association of Official Analytical Chemistry. $18^{\text {th }}$ ed. Gaithersburg, 2005.
CAVALCANTI, J.J.V.; PAIVA, J.R.de; BARROS, L.de M.; CRISOSTOMO, J.R.; CORREA, M.P.F. Repetibilidade e número de avaliações necessárias a seleção de clones de cajueiro anão precoce. Fortaleza : Embrapa Agroindústria Tropical, 1999. $12 \mathrm{p}$.

CORREAA, G.C.; NAVES, R.V.; ROCHA, M.R.; CHAVES, L.J.; BORGES, J.D. Determinações físicas em frutos e sementes de baru (Dipteryx alata Vog.), cajuzinho (Anacardium othonianum Rizz.) e pequi (Caryocar brasiliense Camb.), visando melhoramento genético. Bioscience Journal, Uberlândia, v.24, n.4, p.42-7, 2008.

COSTA, J.D.; LEDO, A.D.S.; OLIVEIRA, M.D.. Estimativas de repetibilidade de características de frutos de cupuaçuzeiro no Estado do Acre. Revista Brasileira de Fruticultura, Jaboticabal. SP, v.19, n.3, p.313-318, 1997.

CRUZ, C.D. Programa GENES: Aplicativo computacional em genética e estatística. Versão Windows. Viçosa: UFV, 2001. 648p.

CRUZ, C.D.; REGAZZI, A.J. Modelos biométricos aplicados ao melhoramento genético. Viçosa: UFV, 2001. 390p

CRUZ, C.D.; REGAZZI, A.J. Modelos biométricos aplicados ao melhoramento genético. Viçosa : UFV, 1994. 390p.

DIAS, L.A.S.; BARROS, W.S. Biometria experimental. Viçosa: Suprema Gráfica Editora, 2009.

FALCONER, D.S. Introdução à genética quantitativa. Viçosa: UFV, 1987. 279p.

FONSECA, C.E.L.; ESCOBAR, J.R.; BUENO, D.M. Variabilidade de alguns caracteres físicos e químicos do fruto do cupuaçuzeiro. Pesquisa Agropecuária Brasileira, Brasília, DF, v.25, n.7, p.1079-84, 1990.

GERASEEV, L.C.; RIBEIRO, F.L.A.; BONFÁ, H.C.; RUFINO, L.M.A; RIBEIRO JÚNIOR, C.S.; DUARTE, E.R. Cinética da degradação ruminal de dietas contendo farelo de casca de pequi. Ciência Rural, Santa Maria, v.41, n.9, p.1626-31, 2011. 
GONZAGA NETO, L.; MATTUZ, B.H.; SANTOS, C.A.F. Caracterização agronômica de clones de aceroleira (Malpighia spp) na região do submédio São Francisco. Revista Brasileira de Fruticultura, Jaboticabal, v.21, n.2, p.110-5, 1999.

GRIBEL, R.; HAY, J. D. Pollination ecology of Caryocar brasiliense (Caryocaraceae) in Central Brazil Cerrado vegetation. Journal of Tropical Ecology, Cambridge, v.9, n.2, p.199-211, 1993.

LIMA, A.; SILVA, A.M.O; TRINDADE, R.A.; TORRES, R.P.; MANCINI-FILHO, J. Composição química e compostos bioativos presentes na polpa e na amêndoa do pequi (Caryocar brasiliense Camb.). Revista Brasileira de Fruticultura, Jaboticabal, v.29, n.3, p.695-8, 2007.

LOPES, R.; BRUCKNER, C.H.; CRUZ, C.D.; LOPES, M.T.G.; FREITAS, G.B.G. Repetibilidade de características do fruto de aceroleira. Pesquisa Agropecuária Brasileira, Brasília, DF, v.36, n.3, p.507-13, 2001.

LUZ, G.R.; RODRIGUES, P.M.S.; MENINO, G.C.O.; COUTINHO, E.S.; NUNES, Y.R.F. Caracterização física de frutos e putâmens e taxa de ataque por Carmenta sp. a pequizeiros (Caryocar brasiliense Camb.) no norte de Minas Gerais. Revista Brasileira de Fruticultura, Jaboticabal, v.33, n.3, p.746-56, 2011.

MELO JR, A.F.; CARVALHO, D.; PÓVOA, J.S.R.; BEARZOTI, E. Estrutura genética de populações naturais de pequizeiro (Caryocar brasiliense Camb.). Scientia Forestalis, Amsterdam, n.66, p.56-65, 2004.

NAVES, R.V.; NASCIMENTO, J.L.; SOUZA, E.R.B. Pequi: série frutas nativas. Jaboticabal: Funep, 2010. 37p.

OLIVEIRA, M.E.B.; GUERRA, N.B.; MAIA, A.H.N.; ALVES, R.E.; MATOS, N.M.S.; SAMPAIO, F.G.M.; LOPES, M.M.T. Características químicas e físico-químicas de pequis da chapada do Araripe, Ceará. Revista Brasileira de Fruticultura, Jaboticabal, v.32, n.1, p.114-25, 2010.

OLIVEIRA, M.S.P.; MOURA, E.F. Repetibilidade e número mínimo de medições para caracteres de cacho de bacabi (Oenocarpus mapora). Revista Brasileira de Fruticultura, Jaboticabal, v.32, n.4, p.1173-9, 2010.
PAIVA, J.R. de; RESENDE, M.D.V. de; CORDEIRO, E.R. Avaliação do número de colheitas na produção de progênies de aceroleira, repetibilidade e herdabilidade de caracteres. Revista Brasileira de Fruticultura, Jaboticabal, v.23, n.1, p.102-7, 2001.

RAMOS, K.M.C.; SOUZA, V.A.B. Características físicas e químico-nutricionais de frutos de pequizeiro (Caryocar coriaceum wittm.) em populações naturais da região meio-norte do Brasil. Revista Brasileira de Fruticultura, Jaboticabal, v.33, n.2, p.500-8, 2011.

RESENDE, M.D.V. Genética biométrica e estatística no melhoramento de plantas perenes. Brasília: Embrapa Informação Tecnológica, 2002. 975p.

RIBEIRO, R.F. Pequi: o rei do cerrado, roendo o fruto sertanejo por todos os lados. Belo Horizonte: Rede Cerrado/Rede/CAA-nm/CAPO-VALE, 2000. $62 \mathrm{p}$.

RODRIGUES, L.J.; VILAS BOAS, V.de B.; PAULA, N.R.F.; ALCÂNTARA, E.M. Caracterização do desenvolvimento de pequi (Caryocar brasiliense) temporão do sul de Minas Gerais. Pesquisa Agropecuária Tropical, Goiânia, v.39, n.3, p.2605, 2009 .

SILVA, D.B.; JUNQUEIRA, N.T.V.; SILVA, J.A.; PEREIRA, A.V.; SALVIANO, A.; JUNQUEIRA, G.D. Avaliação do potencial de produção do "pequizeiro-anão" sob condições naturais na região sul do estado de Minas Gerais. Revista Brasileira de Fruticultura, Jaboticabal, v.23, n.3, p.726-9, 2001a.

SILVA, D.B.; SILVA, J.A.; ANDRADO, L.R.M.; JUNQUEIRA, N.T.V. Frutas do cerrado. Brasília: Embrapa Informação Tecnológica, 2001b. 178p.

SILVA, F.H.L.; FERNANDES, J.S.C.; ESTEVES, E.A.; TITON, M.; SANTANA. R.C. Populações, matrizes e idade da planta na expressão de variáveis físicas em frutos do pequizeiro. Revista Brasileira de Fruticultura, Jaboticabal, v.34, n.3, p.806-13, 2012.

SIQUEIRA, E.R. Coeficiente da repetibilidade de produção de frutos de coqueiro comum. Pesquisa Agropecuária Brasileira, Brasília, DF, v.17, n.3, p.573-4, 1982. 
SOARES JÚNIOR, M.S.; REIS, R.C.; BASSINELLO, P.Z.; LACERDA, D.B.C.; KOAKUZU, S.N.; CALIARI, M. Qualidade de biscoitos formulados com diferentes teores de farinha de casca de pequi. Pesquisa Agropecuária Tropical, Goiânia, v.39, n.2, p.98-104, 2009.

VERA, R.; NAVES, R.V.; NASCIMENTO, J.L.; CHAVES, L.J. LENDRO, W.M.; SOUZA, E.R.B. Caracterização física de frutos de pequizeiro (Caryocar brasiliense Camb.) no estado de Goiás. Pesquisa Agropecuária Tropical, Goiânia, v.35, n.2, p.71-9, 2005.

VERA, R.; SOUZA, E.R.B.; FERNANDES, E.P.; NAVES, R.V.; SOARES JÚNIOR, M.S.; CALIARI, M.; XIMENES, P.A. Caracterização física e química de frutos do pequizeiro (Caryocar brasiliense Camb.) oriundos de duas regiões no estado de Goiás, Brasil. Pesquisa Agropecuária Tropical, Goiânia, v.37, n.2, p.93-9, 2007.
VILELA, G. F. Variações em populações naturais de Caryocar brasiliense Camb. (Caryocaraceae): fenológicas, genéticas e de valores nutricionais de frutos. 1998. 88 f. Dissertação (Mestrado em Engenharia Florestal) - Universidade Federal de Lavras, Lavras, 1998.

YUN, R.; ZHONG, M.; WANG, H.X.; WEI, W.; HU, Z.A.; QIAN, Y.Q. Study on DNA diversity of Liaodong populations at Dongling mountain region. Acta Botanica Sinica, São Paulo, v.40, p.169-75, 1998. 